\title{
Influence of Shot Peening Treatment in Erosion Wear Behavior of High Chromium White Cast Iron
}

\author{
Juan González *, Luis Borja Peral, Alfredo Zafra and Inés Fernández-Pariente \\ Department of Material Science and Engineering, Campus de Gijón, Edificio Departamental Este, University of \\ Oviedo, 33203 Gijón, Spain \\ * Correspondence: uo156740@uniovi.es; Tel.: +34-6966-69-5134
}

Received: 9 July 2019; Accepted: 20 August 2019; Published: 27 August 2019

\begin{abstract}
High alloy white cast irons (WCI) play an important role in many industrial fields such as mining, cement industry, or grinding due to their high hardness and wear resistance. In all these processes, white cast iron components must work under erosion and abrasion conditions. Many investigations have been carried out with the aim of improving the mechanical properties of this type of alloys. Wear resistance depends on the mechanical properties, mainly hardness. Thus, the WCI are typically heat treated in order to modify its microstructure, improving its tribological and wear behavior. The aim of this study is to propose a mechanical surface treatment, shot peening, as an alternative to global heat treatments, due to its capacity to induce phase transformation and microstructural modification, at the same time that it improves the mechanical properties of materials. Characterization of different treated samples was performed by means of microstructural characterization, X-ray diffraction analysis, SEM observation, hardness and roughness measurements, and erosion tests. The results show that shot peening treatment is able to transform residual austenite and increase hardness in the top surface layer of the material. Both effects contribute to improve the erosion wear behavior of the WCI.
\end{abstract}

Keywords: shot peening; heat treatment; residual austenite; phase transformation; erosion wear resistance

\section{Introduction}

Cast irons have been used in industrial applications for several decades. This kind of materials were discovered in 1940 [1] and are defined as an iron alloy with a carbon content from $2.11 \%$ to $6.67 \%$ (commonly between $2.5 \%$ and $4.5 \%$ ). Elements such as silicon, manganese, phosphorous, or sulfur are often present in their chemical composition [2]. Depending on the silicon content, cast irons are classified as white cast irons or grey cast irons, the latter having between $1 \%$ and $3 \%$ of silicon. In white cast irons, carbon appears in the form of cementite instead of graphite, as is the case in grey cast irons. Cementite makes white cast iron brittle and difficult to machine, but at the same time, it confers to the material an extreme hardness, which makes it interesting in erosion and abrasion wear applications. Hence, white cast irons are widely used in many wear resistant components such as grinding rods and balls, rock machining equipment, slurry pumps, brick dies, and mine equipment; that is the reason why they have a widespread use in mineral processing, cement production, and steel manufacturing industries [3-10].

Mechanical behavior of industrial components depends directly on the material's microstructure which, at the same time, depends on its specific chemical composition. With the aim to improve some properties, certain elements are usually added. Chromium is one of the most commonly used in white cast irons, since it improves corrosion resistance and contributes to increasing hardness level. 
High-chromium white cast irons are ferrous alloys containing $1.8-3.6 \% \mathrm{C}$ and $11-30 \% \mathrm{Cr}$, with variable percentages of molybdenum, manganese, copper, and nickel [11]. White cast iron microstructure depends specifically on three factors: Chemical composition, cooling rate during the solidification stage, and cooling rate after the solidification. Generally, at the end of the solidification, the high-chromium white cast iron is composed by a primary phase (dentritic austenite) and a eutectic compound formed by austenite and $\mathrm{K}_{2}$ carbides $\left(\mathrm{M}_{7} \mathrm{C}_{3}\right)$ and sometimes by small secondary carbides $\left(\mathrm{K}_{2}\left(\mathrm{M}_{7} \mathrm{C}_{3}\right)\right)$ and/or $\mathrm{K}_{\mathrm{c}}$ carbides $\left(\mathrm{M}_{3} \mathrm{C}\right)[12,13]$.

Microstructural transformations during cooling depend on the cooling rate and the chemical composition of the cast iron [14,15]. Austenite (both dendrites and the eutectic compound), which is rich in carbon and chromium, can be transformed into martensite (usually partially), while eutectic carbides do not transform during cooling after solidification [16]. In addition, during the cooling stage and after the solidification process secondary carbides (smaller than eutectic ones) can precipitate in the austenitic/martensite matrix $[17,18]$. This usually occurs when the chromium content is greater than $15 \%$ [15]. In this case, the matrix constituent contains very hard precipitated secondary carbides $\mathrm{K}_{\mathrm{c}}\left(\mathrm{M}_{3} \mathrm{C}\right)(1200-1600 \mathrm{HV})$ [19], which confer better wear resistance to the material in comparison with cast iron with less amount of chromium. In this case, the constituent matrix does not contain this kind of secondary carbides [20-23].

Another important parameter that influences the wear resistance is the amount of residual austenite. Wear resistance improves when the amount of residual austenite decreases [24]. In general, martensitic structures are supposed to be more wear resistant than austenitic ones [25].

In order to modify cast iron microstructures, heat treatments are often used, being the transformation ratio and hardening response highly dependent on the treatment conditions and chemical composition of the alloy [8]. Properties can also be controlled and modified by means of heat treatments. These can modify hardness, microstructure morphology, precipitated carbides type, and their distribution in the matrix. In other words, it is necessary to apply heat treatments to modify microstructure, phases, morphology, and carbides distribution, since they optimize the final properties by improving the microstructure of the material [3].

On the other hand, some recent researches have demonstrated that mechanical treatments, besides improving mechanical behavior of materials, can even induce phase transformation [26]. Among these treatments, shot peening (SP) is a popular and extended mechanical surface treatment that consists on impacting the surface of metallic materials by a flow of shots, with enough kinetic energy to induce plastic deformation, introducing compressive residual stresses into the upper layer of the material, which contribute to the surface hardening of the material. These effects are useful to stop or prevent crack propagation $[27,28]$ and contribute to improve fatigue [29-35], corrosion $[35,36]$ and wear $[36,37]$ behavior of components.

In this context and considering that high chromium cast irons are used for wear applications, it could be interesting to increase their hardness, and therefore their wear behavior.

The proposal of this research is to submit an $18 \% \mathrm{Cr}$ white cast iron (one of the most common alloys used as wear parts in slurry transport, mining, minerals, and cement industries) [38] to a shot peening treatment. The aim is to increase its hardness and, at the same time, transforming the residual austenite in the upper layer of the material. In this case, it is possible to obtain a material with a reinforced upper layer that can be useful for applications where surface hardness is required.

The effect of this surface treatment will be compared with the effect of global heat treatments in terms of microstructure, phase composition (XRD analysis), hardness, and wear resistance, by means of erosion tests. 


\section{Material, Specimens, Treatments, Experimental Procedures, and Results}

\subsection{Material and Specimens}

A total of $18 \%$ chromium white cast iron specimens $(18 \% \mathrm{Cr}-\mathrm{WCI})$ were cut from an ingot with a parallelepiped geometry of $10 \times 10 \times 80 \mathrm{~mm}^{3}$. The nominal chemical composition of the cast iron is presented in Table 1.

Table 1. Chemical composition of $18 \%$ chromium white cast iron specimens ( $18 \% \mathrm{Cr}-\mathrm{WCI})$.

\begin{tabular}{lccccc}
\hline \multirow{2}{*}{$\mathbf{1 8} \% \mathrm{Cr}-$ WCI } & $\% \mathrm{C}$ & $\% \mathrm{Si}$ & $\% \mathbf{M n}$ & $\% \mathbf{C r}$ & $\% \mathrm{Mo}$ \\
\cline { 2 - 6 } & 3.01 & 1.17 & 0.82 & 18.2 & 2.05 \\
\hline
\end{tabular}

Specimens were austenitized at $1000{ }^{\circ} \mathrm{C}$ for $6 \mathrm{~h}$ and then air quenched. As this is the typical heat treatment applied to this white cast iron, it will be considered as the reference treatment in this study (18\%Cr-WCI-Q).

\subsection{Treatments}

With the aim to modify the mechanical properties of the quenched material, different series of specimens were submitted to heat and mechanical (shot peening) treatments.

\subsubsection{Heat Treatments}

One series of specimens were submitted to a tempering treatment, at $500{ }^{\circ} \mathrm{C}$ for $8 \mathrm{~h}$, and the other series were submitted to a double tempering treatment, $500{ }^{\circ} \mathrm{C}$ for $8 \mathrm{~h}$ each, in a carbolite oven (Carbolite Gero, Hope, United Kingdom). The double treatment is common in this kind of material in order to transform the residual austenite that has not been transformed during the first tempering treatment. These series will be referenced in the text as $18 \% \mathrm{Cr}-\mathrm{WCI}-\mathrm{T}$ and $18 \% \mathrm{Cr}-\mathrm{WCI}-2 \mathrm{~T}$, respectively.

\subsubsection{Shot Peening Treatment}

With the idea of evaluating the possible transformation of the residual austenite by means of plastic deformation, as well as increasing the surface hardness, other series of samples were submitted to shot peening treatments, after being quenched and tempered at $1000^{\circ} \mathrm{C}-1 \mathrm{~h}+$ air cooling.

The specimens were subjected to SP treatment using an air blast SP machine, GUYSON Euroblast 4 PF model with tank type G27, motorized cyclone type 75/16 and DC400 dust collector model, (Materias Primas Abrasivas, S.L., Barcelona, Spain) with an Almen Intensity of 10A, commonly used in the industry for hard metallic materials, and conventional coverage (100\%). Almen Intensity and surface coverage are the most important measuring parameters of SP; these are directly related with the total kinetic energy of the process and influence the total accumulated plastic strain. SP parameters are shown in Table 2. This series will be referenced in the text as $18 \% \mathrm{Cr}$-WCI-SP.

Table 2. Shot peening parameters.

\begin{tabular}{ccccc}
\hline Treatment & $\begin{array}{c}\text { Shot Diameter } \\
(\mathbf{m m})\end{array}$ & $\begin{array}{c}\text { Almen Intensity } \\
\mathbf{( 0 . 0 0 0 1} \text { in.) }\end{array}$ & $\begin{array}{c}\text { Time of Treatment } \\
\mathbf{( s )}\end{array}$ & $\begin{array}{c}\text { Surface Coverage } \\
\mathbf{( \% )}\end{array}$ \\
\hline $\begin{array}{c}\text { Conventional shot } \\
\text { peening }\end{array}$ & 0.3 & $10 \mathrm{~A}$ & 8 & 100 \\
\hline
\end{tabular}

Zirshot Y300 shots (Saint Gobain, Spain) were used in all peening treatments performed in this study. Chemical compositions and mechanical properties of shot peening projectiles presented in Table 3. 
Table 3. Chemical composition (wt.\%) and mechanical properties of shots.

\begin{tabular}{ccccc}
\hline Shots & $\begin{array}{c}\text { Chemical } \\
\text { Composition }(\mathbf{\%} w \mathbf{w})\end{array}$ & $\begin{array}{c}\text { Diameter } \\
(\mathbf{m m})\end{array}$ & $\begin{array}{c}\text { Density } \\
\left(\mathbf{g} / \mathbf{c m}^{3}\right)\end{array}$ & Hardness (HV) \\
\hline Zirshot $\mathrm{Y} 300$ & $\begin{array}{c}\mathrm{ZrO}_{2}>75 \% \\
\mathrm{SiO}_{2}<25 \%\end{array}$ & $\sim 0.3$ & 4.6 & 1000 \\
\hline
\end{tabular}

Table 4 summarizes the names of all the series and the treatment they were submitted to.

Table 4. Series designation and specifications.

\begin{tabular}{cc}
\hline $18 \% \mathrm{Cr}-W C I-\mathrm{Q}$ & $18 \% \mathrm{Cr}-\mathrm{WCI}+$ Austenizing $\left(1000^{\circ} \mathrm{C}-6 \mathrm{~h}\right)+$ Air Quenching \\
$18 \% \mathrm{Cr}-$ WCI-T & $18 \% \mathrm{Cr}-\mathrm{WCI}-\mathrm{Q}+$ Tempering $\left(500{ }^{\circ} \mathrm{C}-8 \mathrm{~h}\right)$ \\
$18 \% \mathrm{Cr}-$ WCI-2T & $18 \% \mathrm{Cr}-\mathrm{WCI}-\mathrm{Q}+$ Double tempering $\left(500{ }^{\circ} \mathrm{C}-8 \mathrm{~h}\right)$ \\
$18 \%$ Cr-WCI-SP & $18 \% \mathrm{Cr}-$ WCI-Q + SP $(100 \%$ coverage $)$ \\
\hline
\end{tabular}

\subsection{Optical Microscopy Analysis}

To analyze microstructural changes after the different treatments, samples were metallographically prepared and observed by means of optical and electronic (SEM JEOL JSM 5600, Tokyo, Japan) microscopes. Some samples of each series were cross sectioned, impregnated in mounting resin, ground sequentially with a range of up to 1200 grit $\mathrm{SiC}$ sandpapers, subsequently polished using soft cloths with abrasive diamond paste (grain sizes of $6 \mu \mathrm{m}$ and $1 \mu \mathrm{m}$ ), and finally etched with a $2 \%$ Nital solution.

Figure 1 shows the microstructures obtained from an optical analysis of $18 \% \mathrm{Cr}-\mathrm{WCI}$ specimens after all different treatments (thermal and mechanical). After $1000{ }^{\circ} \mathrm{C}-6 \mathrm{~h}$ quenching and air-cooling treatment, the microstructure reveals small carbides $\mathrm{K}_{2}\left(\mathrm{Cr}_{7} \mathrm{C}_{3}\right)$ in proeutectic austenite/martensite, and a matrix formed by $\mathrm{K}_{2}\left(\mathrm{Cr}_{7} \mathrm{C}_{3}\right)$ eutectic carbides and eutectic austenite/martensite (Figure 1a). After a tempering treatment $\left(500{ }^{\circ} \mathrm{C}-8 \mathrm{~h}\right)$, the optical microstructure reveals small $\mathrm{k}_{2}\left(\mathrm{Cr}_{7} \mathrm{C}_{3}\right)$ carbides much more homogenous in a tempered martensite and unaltered eutectic $\mathrm{K}_{2}\left(\mathrm{Cr}_{7} \mathrm{C}_{3}\right)$ carbides (Figure $1 \mathrm{~b}$ ). After a double tempering treatment $\left(500{ }^{\circ} \mathrm{C}-8 \mathrm{~h}\right.$ each) the microstructure, observed by optical microscopy, seems quite similar to the simple tempered one (Figure 1c). Results from the X-ray analysis (see point 2.3) also reveal the presence of secondary carbides $\mathrm{Kc}_{\mathrm{c}}\left(\mathrm{M}_{3} \mathrm{C}\right)$.

Figure $1 \mathrm{~d}$ shows the microstructure of quenched specimen with SP treatment. Because of the high hardness of the material, the thickness of the surface affected layer is not so large, around $10 \mu \mathrm{m}$ (orange square in the micrograph). In this zone, a greater density of small $\mathrm{K}_{2}$ carbides is present in proeutectic austenite/martensite. The rest of the microstructure is similar to the $18 \% \mathrm{Cr}-\mathrm{WCI}-\mathrm{Q}$.

All these data will be corroborated by X-ray diffraction analysis and SEM observation exposed in the next sections.

\subsection{Phase Analysis by X-Ray Diffraction and SEM Observation}

In order to support the aforementioned microstructural observations and to quantify phase changes caused by the different treatments, $\mathrm{X}$-ray diffraction analysis was performed on the surface of the samples by means of a Seifert XRD 3000 T/T diffractometer (Seifert, Massillon, OH, USA). Parfocal Bragg-Brentano optical configuration was used with a coupled Theta-Theta movement, i.e., inverse rotation of tube and detector (being placed at the end of the primary and secondary diffractometer arms, respectively) and with the specimen fixed in the center of the goniometer. Furthermore, the radiation is emitted by a thin line molybdenum focus working at $40 \mathrm{kV} \times 40 \mathrm{~mA}$, and it is then monochromatized to the $K \alpha$ doublet $\left(\lambda_{1}=0.709316 \AA\right.$ and $\left.\lambda_{2}=0.713607 \AA\right)$ by means of a primary filter of zirconium and a secondary monochromator of highly oriented pyrolytic graphite (HOPG). Finally, the collimation of radiation is achieved by the following fixed slit set: $1^{\circ}$-divergence, $2^{\circ}$-antichatter, and $0.1 \mathrm{~mm}$-receiving 
slits. On the other hand, patterns were registered by a scintillation detector (Nal (Tl)) between $12^{\circ} \mathrm{y}$ $36^{\circ}$ in 2 Theta on fixed mode, with steps of $0.025^{\circ}$ and $60 \mathrm{~s}$ per point.

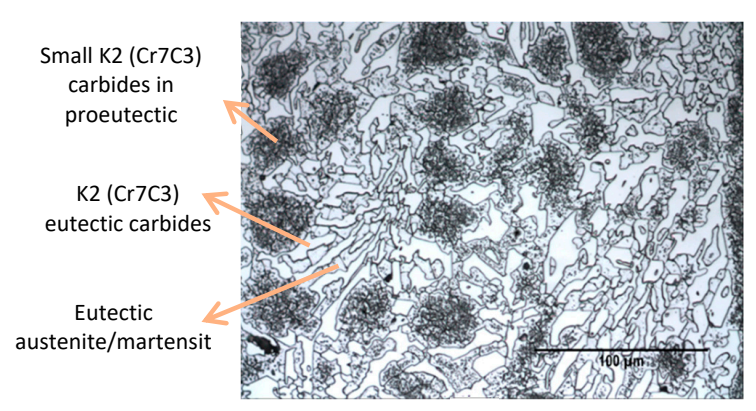

a

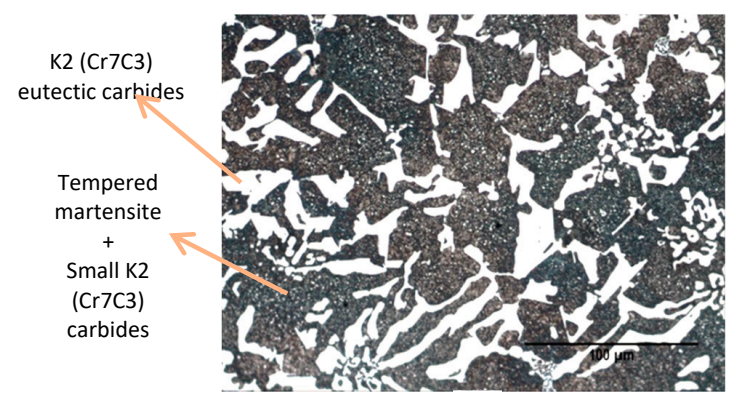

c
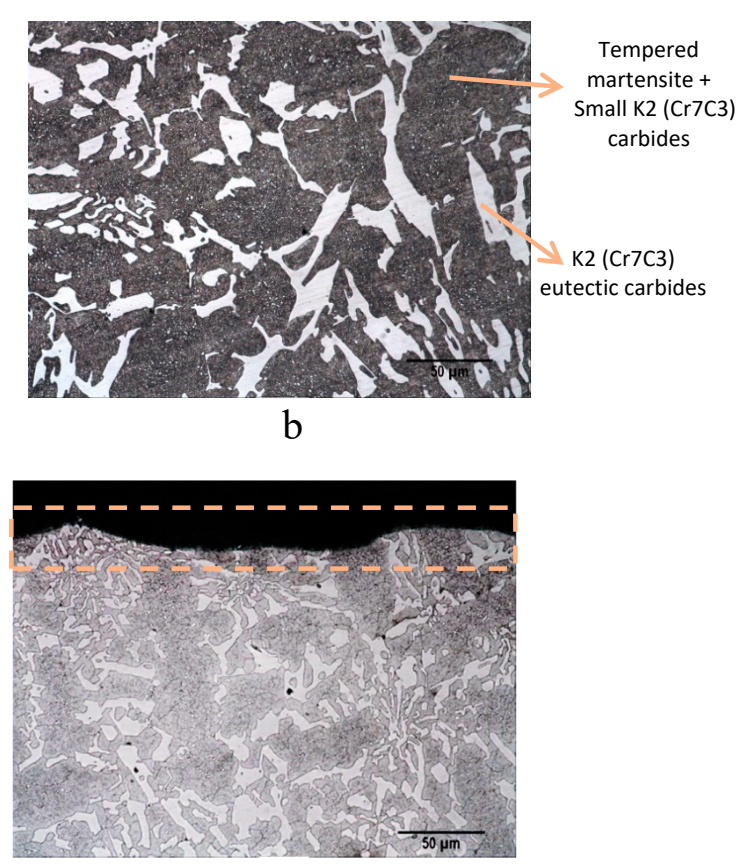

d

Figure 1. Microstructures (Optical microscope) of $18 \% \mathrm{Cr}-\mathrm{WCI}$ specimens after different treatments. (a) 18\%Cr-WCI-Q (500×); (b) 18\%Cr-WCI-T (500×); (c) 18\%Cr-WCI-2T (500×); (d) 18\%Cr-WCI-SP (500×).

A fraction of present phases was calculated by means of the analysis of the diffractograms obtained by X-ray analysis (Figure 2) using Rietveld structural refinement method [39]. These data are discussed, together with SEM analysis (Figure 3), to justify the obtained results.

X-ray analysis performed on 18\%Cr-WCI-Q sample (Figure $2 \mathrm{a}$ ) reveals the presence of martensite, austenite, and $\mathrm{K}_{2}\left(\mathrm{Cr}_{7} \mathrm{C}_{3}\right)$ carbides in 55, 13, and $32 \%$ of the weight, respectively. These results are consistent with the SEM image (Figure $3 a)$ where it is possible to see small $\mathrm{K}_{2}\left(\mathrm{Cr}_{7} \mathrm{C}_{3}\right)$ carbides in proeutectic austenite/martensite, and a eutectic matrix form by $\mathrm{K}_{2}\left(\mathrm{Cr}_{7} \mathrm{C}_{3}\right)$ eutectic carbides and eutectic austenite/martensite. This analysis matches the optical microscopic analysis exposed earlier.

After tempering treatment $\left(500{ }^{\circ} \mathrm{C}-8 \mathrm{~h}\right)$, destabilization of austenite took place. DRX analysis (Figure $2 \mathrm{~b}$ ) shows the disappearance of practically all the austenite (1\% remaining) giving place to an increment of martensite (from $55 \%$ to $67 \%$ ). The proportion of the $\mathrm{k}_{2}\left(\mathrm{Cr}_{7} \mathrm{C}_{3}\right)$ carbides remains constant. SEM observation (Figure $3 b$ ), in agreement with optical analysis, shows a more homogenous distribution of small $\mathrm{K}_{2}\left(\mathrm{Cr}_{7} \mathrm{C}_{3}\right)$ carbides.

After double tempering treatment $\left(500{ }^{\circ} \mathrm{C}-8 \mathrm{~h}\right.$ each) the residual austenite was still around $1 \%$, while a partial redissolution of $\mathrm{K}_{2}$ carbides took place, decreasing to $27 \%$. On the other hand, superior bainite $\left(\mathrm{CFe}_{3}\right)(12 \%)$ is formed into the matrix (Figure 2c). SEM analysis of $18 \% \mathrm{Cr}-\mathrm{WCI}-2 \mathrm{~T}$ sample allows to detect the above-mentioned phases (Figure $3 \mathrm{c}$ ): Eutectic $\mathrm{K}_{2}\left(\mathrm{Cr}_{7} \mathrm{C}_{3}\right)$ carbides (darker) and small $\mathrm{K}_{2}\left(\mathrm{Cr}_{7} \mathrm{C}_{3}\right)$ (spherical) together with fine and elongated $\left(\mathrm{CFe}_{3}\right)$ carbides in a matrix of martensite.

Figure $2 \mathrm{~d}$ shows the diffractogram of semiquantitative analysis of the $18 \% \mathrm{Cr}$-WCI-SP sample. Results show that plastic deformation induced by shot peening treatment induced the transformation of all the residual austenite. In this case, destabilization of the austenite tends to form small $\mathrm{K}_{2}\left(\mathrm{Cr}_{7} \mathrm{C}_{3}\right)$ carbides on the top surface of the sample, as supported by the $\mathrm{X}$-ray analysis. These carbides are also visible on SEM observation (Figure 3d). Zircona $\left(\mathrm{ZrO}_{2}\right)$ phase is also present in the XRD analysis of this sample (7\%) (Figure 2d). This is because the shots used in the shot peening treatment were made of Zircona, which could be embedded on the material surface. 

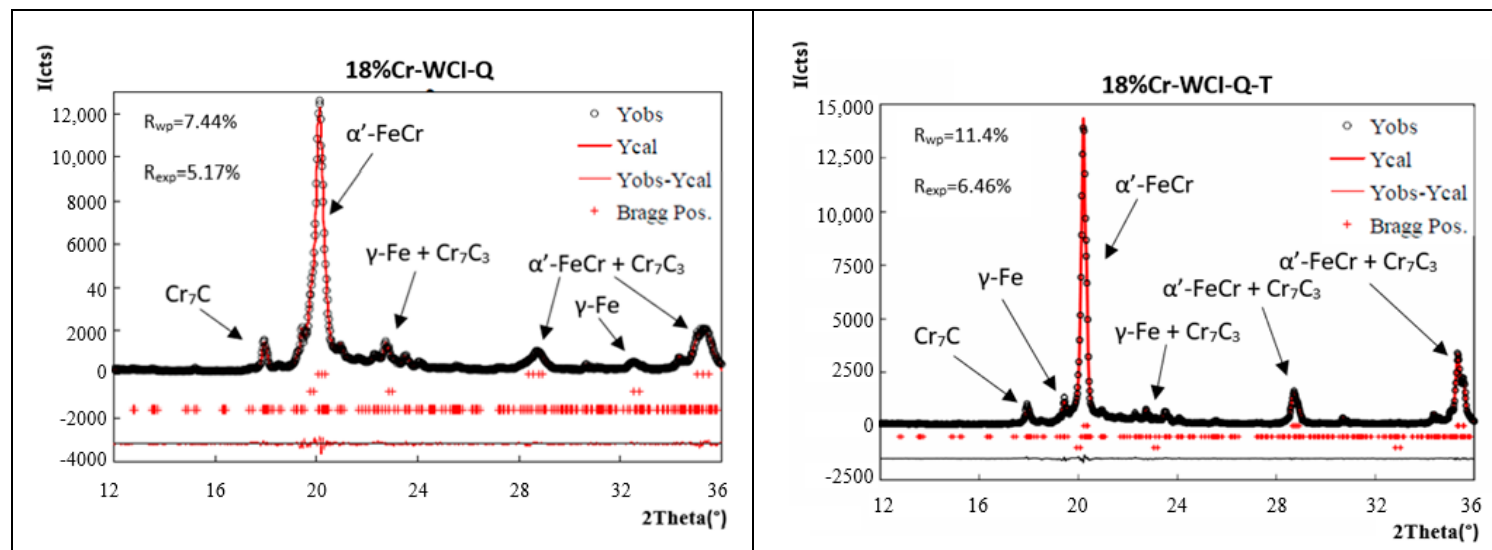

\begin{tabular}{|c|c|c|}
\hline Phase & Content (\%) & $\mathbf{2 0}\left({ }^{\circ}\right)$ \\
\hline Martensite $\left(\alpha^{\prime}-\mathrm{FeCr}\right)$ & 55 & $20 / 28.5 / 35$ \\
\hline Austenite $(\gamma-\mathrm{Fe})$ & 13 & $23 / 32$ \\
\hline Carbides $\mathrm{k}_{2}\left(\mathrm{Cr}_{7} \mathrm{C}_{3}\right)$ & 32 & $18 / 23 / 28.5 / 32 / 35$ \\
\hline
\end{tabular}

\begin{tabular}{|c|c|c|}
\hline Phase & Content (\%) & $\mathbf{2 0}\left({ }^{\circ}\right)$ \\
\hline Martensite $\left(\alpha^{\prime}-\mathrm{FeCr}\right)$ & 67 & $20 / 28.5 / 35$ \\
\hline Austenite $(\gamma-\mathrm{Fe})$ & 1 & $19 / 23$ \\
\hline Carbides $\mathrm{k}_{2}\left(\mathrm{Cr}_{7} \mathrm{C}_{3}\right)$ & 32 & $18 / 23 / 28.5 / 35$ \\
\hline
\end{tabular}

a

b
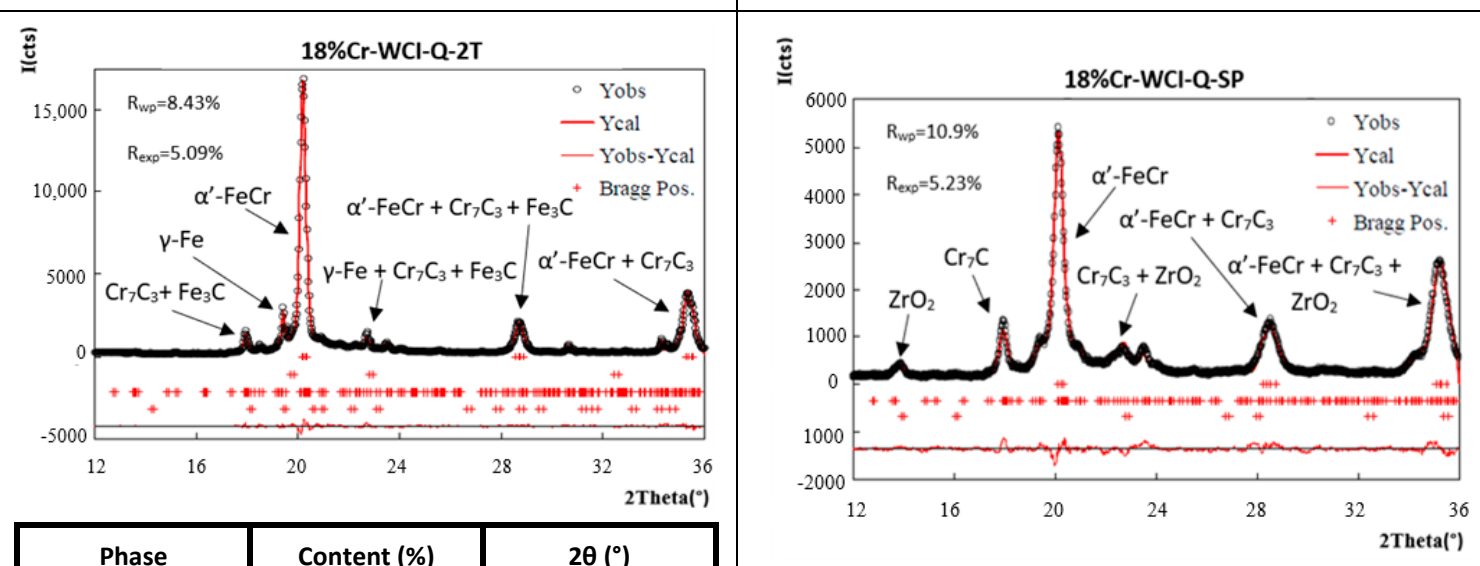

\begin{tabular}{|c|c|c|}
\hline Phase & Content (\%) & $\mathbf{2 \theta}\left({ }^{\circ}\right)$ \\
\hline Martensite $\left(\alpha^{\prime}-\mathrm{FeCr}\right)$ & 60 & $20 / 28.5 / 35$ \\
\hline Austenite $(\gamma-\mathrm{Fe})$ & 1 & $19 / 23$ \\
\hline Carbides $\mathrm{k}_{2}\left(\mathrm{Cr}_{7} \mathrm{C}_{3}\right)$ & 27 & $18 / 23 / 28.5 / 35$ \\
\hline Cementite $\left(\mathrm{Fe}_{3} \mathrm{C}\right)$ & 12 & $18 / 23 / 28.5$ \\
\hline & C \\
\hline
\end{tabular}

\begin{tabular}{|c|c|c|}
\hline Phase & Content (\%) & $\left.\mathbf{2 \theta} \mathbf{(}^{\circ}\right)$ \\
\hline Martensite $\left(\alpha^{\prime}-\mathrm{FeCr}\right)$ & 43 & $20 / 28.5 / 35$ \\
\hline Carbides $\mathrm{k}_{2}\left(\mathrm{Cr}_{7} \mathrm{C}_{3}\right)$ & 50 & $18 / 23 / 28.5 / 35$ \\
\hline Zircona $\left(\mathrm{ZrO}_{2}\right)$ & 7 & $14 / 23 / 35$ \\
\hline \multicolumn{3}{|c}{} \\
\hline
\end{tabular}

Figure 2. Phase analysis by $\mathrm{X}$-ray diffraction after different treatments. (a)18\%Cr-WCI-Q; (b) $18 \% \mathrm{Cr}-\mathrm{WCI}-\mathrm{T}$; (c) $18 \% \mathrm{Cr}-\mathrm{WCI}-2 \mathrm{~T}$; (d) $18 \% \mathrm{Cr}-\mathrm{WCI}-\mathrm{SP}$. 
a

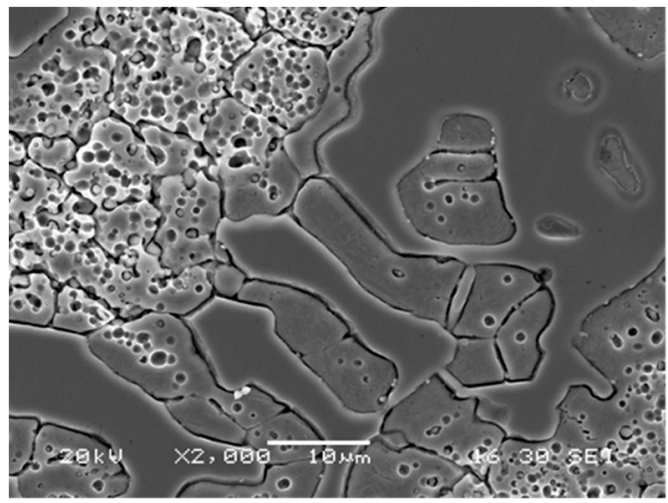

C

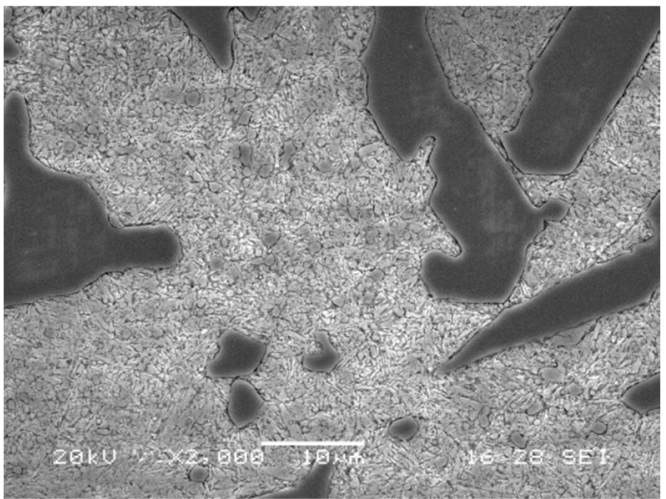

b
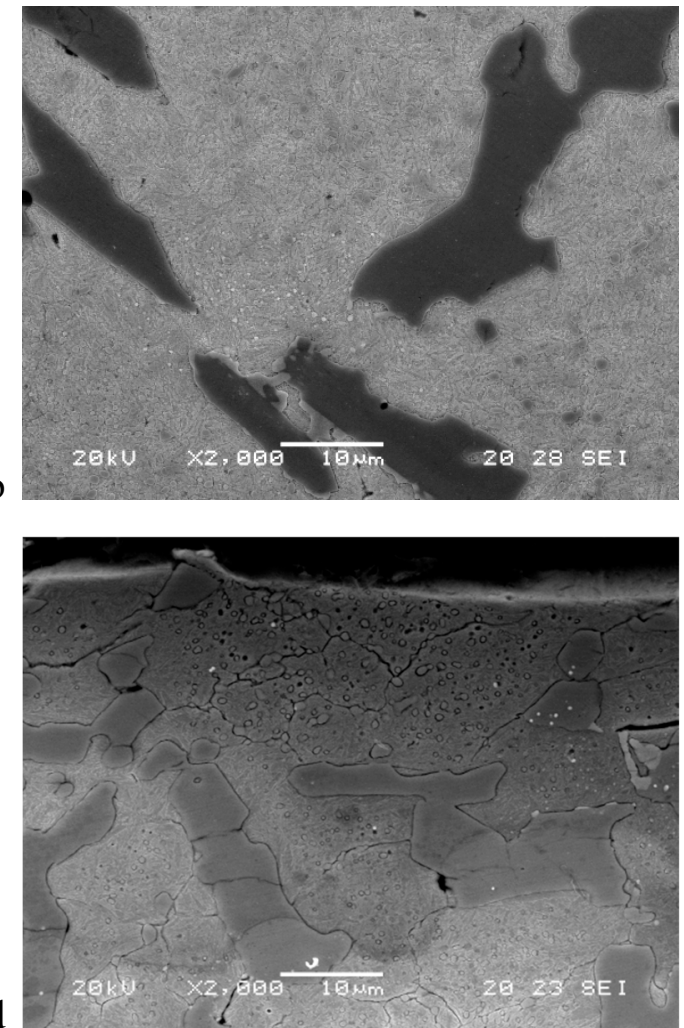

Figure 3. SEM microstructures of $18 \% \mathrm{Cr}$-WCI specimens after different treatments. (a) $18 \% \mathrm{Cr}$-WCI-Q; (b) $18 \% \mathrm{Cr}-\mathrm{WCI}-\mathrm{T}$; (c) $18 \% \mathrm{Cr}-\mathrm{WCI}-2 \mathrm{~T}$; (d) $18 \% \mathrm{Cr}$-WCI-SP.

In order to corroborate the results of residual austenite obtained by means of Seifert XRD 3000 $\mathrm{T} / \mathrm{T}$ diffractometer analysis (Seifert, Massillon, OH, USA), new measurements were carried out with a Stresstech G3R diffractometer (Stresstech, Jyväskylä, Finland). Knowing the carbides percentage previously, the austenite measurements are based on the calculation of the area under the ferrite and austenite diffraction peaks. This area is proportional to the content of every phase [40]. The diffraction peak was detected in $45^{\circ}$ position of the rotation angle, $\Psi$, and 20 different positions were measured around $\varphi$ angle, which is located on the plane specimen, between $-45^{\circ}$ and $+45^{\circ}$ angle position. The measurements were taken considering four peaks (two for the ferrite and two for the austenite). Firstly, making use of the A and B detectors, the two austenite peaks located in $130^{\circ}$ and $80^{\circ}$ were measured respectively; after that, detectors were changed to the ferrite angles, $156.4^{\circ}$ and $106.1^{\circ}$, and the measurements were repeated in the same 20 positions from $-45^{\circ}$ to $+45^{\circ}$, always in $\Psi$ angle, $45^{\circ}$ position. The parameters used are summarized in Table 5.

Table 5. Parameters used in residual austenite measurements with Stresstech G3R diffractometer.

\begin{tabular}{cccc}
\hline Maximum Voltage (kV) & $\mathbf{3 0}$ & Maximum Intensity (mA) & $\mathbf{6 . 7}$ \\
\hline Radiation & $\mathrm{Cr} \mathrm{K} \alpha . \lambda=0.2291 \mathrm{~nm}$ & Carbides $(\%)$ & $0-\mathrm{Vc}^{*}$ \\
\hline Filter & Vanadio & Colimator diameter $(\mathrm{mm})$ & 5 \\
\hline \multirow{2}{*}{ Austenite plane } & $(220)$ & Austenite diffraction angle $\left(2 \theta^{\circ}\right)$ & 130 \\
& $(200)$ & & 80 \\
\hline \multirow{2}{*}{ Ferrite plane } & $(211)$ & Ferrite diffraction angle $\left(2 \theta^{\circ}\right)$ & 156.4 \\
& $(200)$ & & 106.1 \\
\hline
\end{tabular}

* carbides content. 
The values obtained in each series are shown in Figure 4 and the observed trend agrees with the measurements obtained using the Seifert device.

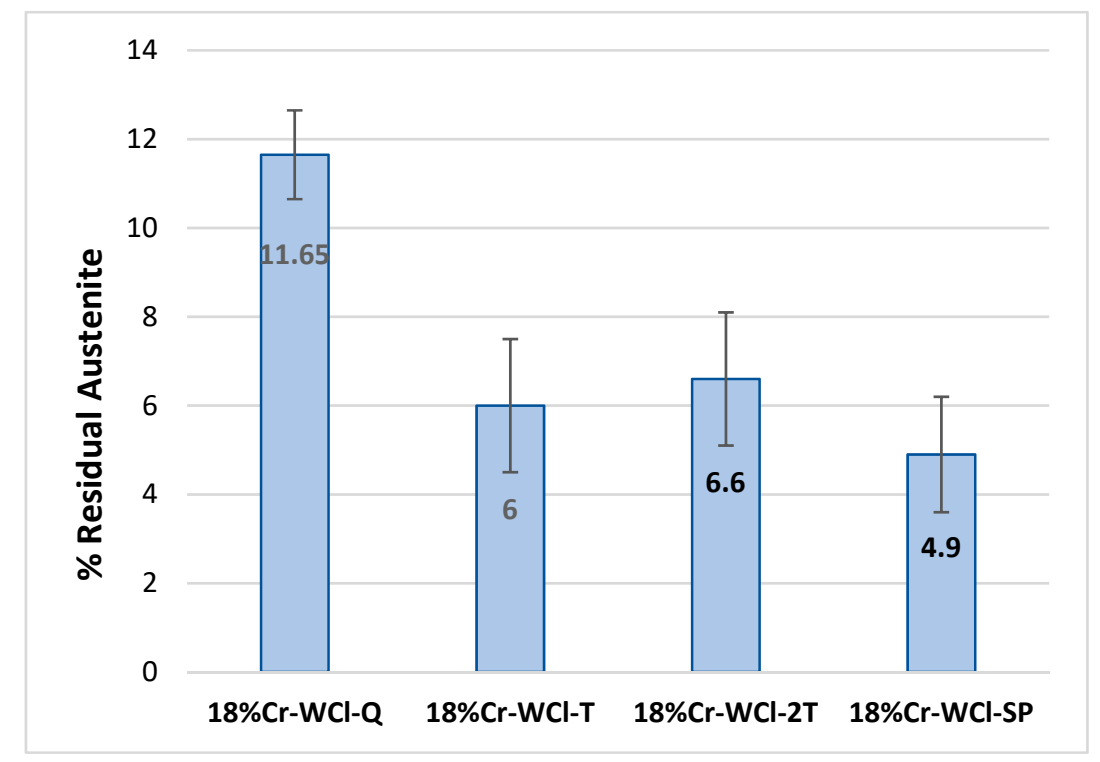

Figure 4. Residual austenite (\%) in specimens after different treatments.

These results corroborate that SP treatments allow to reduce the amount of residual austenite obtained after quenching due to the induced plastic deformation. A similar effect was observed in the tempered samples but in this case due to the applied heat treatment.

\subsection{Hardness Measurement}

Hardness level after the applied treatments was measured by means of a Vickers microhardness tester (Mahr GmbH, Göttingen, Germany). Measurements were performed in the matrix because hardness of eutectic carbides remains constant after treatments. Hardness values of heat-treated series are shown in Table 6.

Table 6. Series designation and specifications.

\begin{tabular}{cc}
\hline Series & HV \\
\hline $18 \% C r-W C I-Q$ & $783 \pm 12$ \\
$18 \%$ Cr-WCI-T & $575 \pm 9$ \\
$18 \%$ Cr-WCI-2T & $700 \pm 39$ \\
\hline
\end{tabular}

With the aim to assess the hardening induce by SP along the upper layer of the material, microhardness measurements were also taken on the transversal section of the shot peened specimens using a diamond Vickers indenter and applying a maximum force of $100 \mathrm{gf}$. The load was applied gradually at a constant rate of $1 \mathrm{~N} / \mathrm{s}$ with a dwell time of $15 \mathrm{~s}$. Three measurements were performed at each depth and the average value is reported considering the heterogeneity of the material and the error of the different measurements. Variations of the microhardness from the shot peened surface $(0 \mu \mathrm{m}$ in depth) to the bulk material are presented in Figure 5 for $18 \mathrm{Cr}$-WCI-SP samples.

As can be observed from the presented results, tempering treatments contribute to decrease hardness of the samples, while SP treatment increases hardness in the upper layer of the material up to $300 \mu \mathrm{m}$ in depth approximately. The work-hardening and the increase of the amount of small $\mathrm{K}_{2}\left(\mathrm{Cr}_{7} \mathrm{C}_{3}\right)$ carbides induced by SP treatment (Figure $3 \mathrm{~d}$ ) are responsible of this increase. Hardness reaches a peak value of $929 \mathrm{HV}$ at $29 \mu \mathrm{m}$ from the surface, and progressively decreases until reaching a hardness value similar to the tempered specimen, at a depth close to $300 \mu \mathrm{m}$. 


\section{Microhardness}

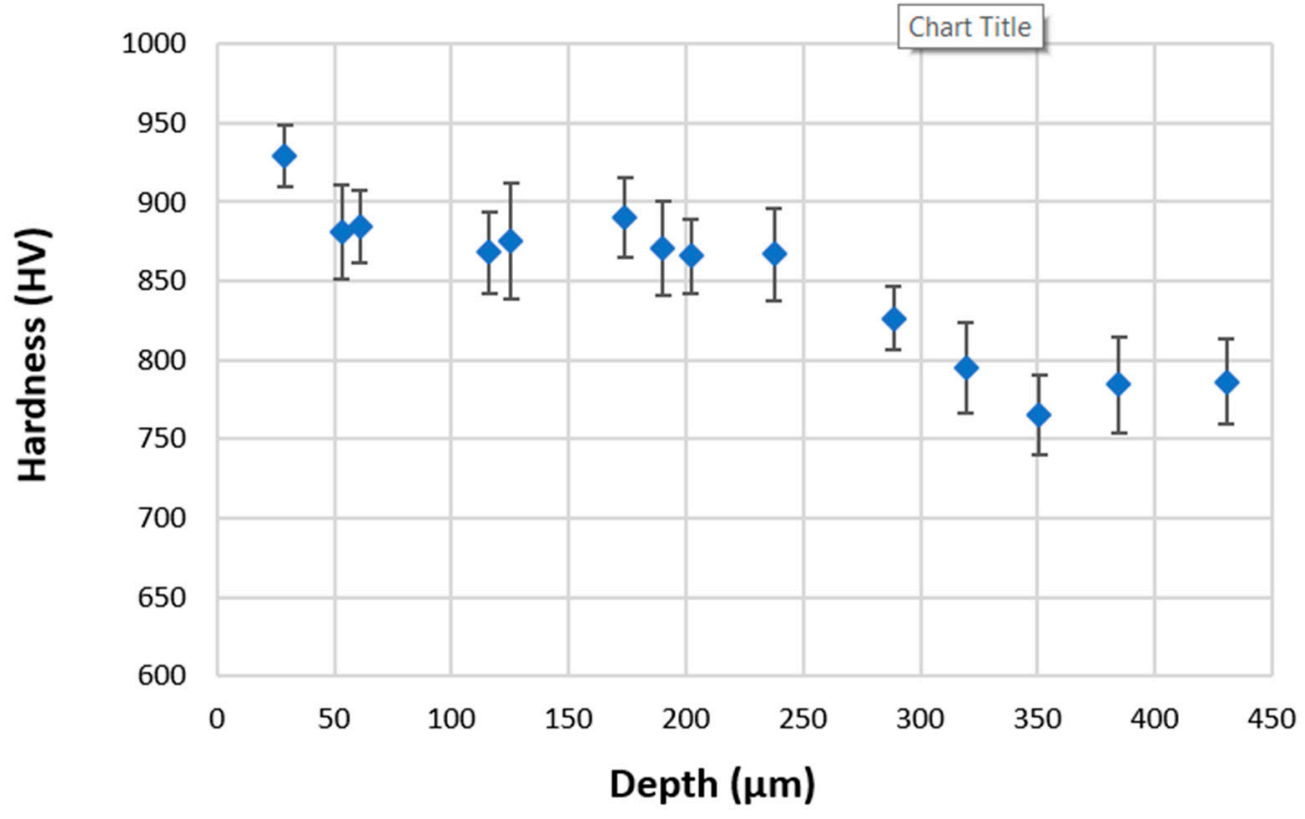

Figure 5. Hardness profile in shot peened specimen.

\subsection{Roughness Measurement}

Shot peening is also known to change the surface topography. Table 7 shows the main roughness parameters, including the arithmetic average of the deviations of the roughness profile from the centerline along the evaluation length $(\mathrm{Ra})$, the quadratic average of the deviations of the roughness profile from the midline along the evaluation length $(\mathrm{Rq})$, and the arithmetic mean of all the peak-valley values of the profile obtained (Rz), with the corresponding standard deviation. A contact roughness tester Mahr Marsurf M300 (Mahr GmbH, Göttingen, Germany) was used following ISO 4287, ASME B46.1DIN 4768 standard. Five measurements on each specimen were averaged, using a Gaussian filter of $0.8 \mathrm{~mm}$. The results show higher surface roughness and more irregularities in SP treated specimens, as confirmed by the optical analysis of the transversal section.

Table 7. Roughness values.

\begin{tabular}{ccc}
\hline Sample & Roughnes Parameter & Average Values \\
\hline \multirow{2}{*}{$18 \%$ Cr-WCI-Q } & $\mathrm{Ra}$ & $0.172 \pm 0.087$ \\
& $\mathrm{Rq}$ & $0.273 \pm 0.142$ \\
$\mathrm{Rz}$ & $1.272 \pm 0.544$ \\
\hline \multirow{2}{*}{$18 \% \mathrm{Cr}-\mathrm{WCI}-\mathrm{T}$} & $\mathrm{Ra}$ & $0.143 \pm 0.091$ \\
& $\mathrm{Rq}$ & $0.172 \pm 0.227$ \\
& $\mathrm{Rz}$ & $0.970 \pm 0.599$ \\
\hline \multirow{2}{*}{$18 \% \mathrm{Cr}-\mathrm{WCI}-2 \mathrm{~T}$} & $\mathrm{Ra}$ & $0.121 \pm 0.088$ \\
& $\mathrm{Rq}$ & $0.152 \pm 0.121$ \\
& $\mathrm{Rz}$ & $0.820 \pm 0.629$ \\
\hline \multirow{2}{*}{$18 \% \mathrm{Cr}-\mathrm{WCI}-\mathrm{SP}$} & $\mathrm{Ra}$ & $0.213 \pm 0.025$ \\
& $\mathrm{Rq}$ & $0.116 \pm 0.034$ \\
& $\mathrm{Rz}$ & $0.662 \pm 0.259$ \\
\hline
\end{tabular}

\subsection{Erosion Tests}

With the purpose of characterizing the influence of mechanical and heat treatments on erosion wear behavior of high chromium white cast irons, erosion tests were performed in a MTDA/G76 
microtest machine (Microtest S.A., Madrid, Spain), following ASTM G76-04 standard. The test consists on impacting the sample surface with a compressed air flux containing corundum particles. The jet nozzle was located $100 \mathrm{~mm}$ over the specimen with an inclination of $90^{\circ}$ from the horizontal. The flux was applied at 1 bar pressure. Even though ASTM G76-04 standard recommends rectangular geometry of samples, approximately $10 \times 30 \mathrm{~mm}^{2}$ and $2 \mathrm{~mm}$ thick, in this study, the specimen's geometry was a parallelepiped of $20 \times 40 \mathrm{~mm}^{2}$ section and $10 \mathrm{~mm}$ thick because of machine requirements. ASTM G76-04 standard accepts such modification as long as it is documented.

In this study, four tests were performed on each sample during different exposure times in different points of the surface sample. Three samples per each series were tested. The weight of the specimens was measured before and after each test in order to calculate weight loss. Erosion rate was calculated as a function of the weight loss over time and is shown in Figure 6. The lower erosion rate, the better erosion behavior.

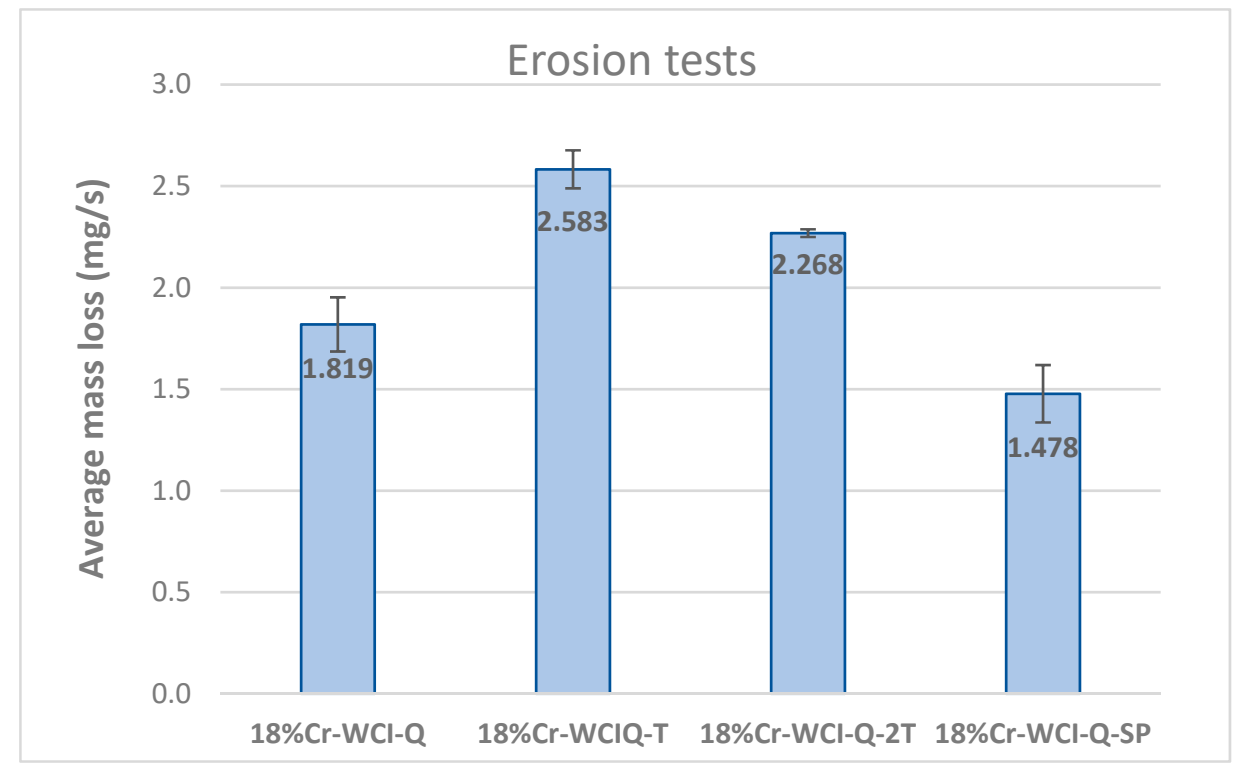

Figure 6. Erosion rate (weight loss over time).

The results show that the $18 \%$-WCI-SP series presents the best erosion wear behavior. The effects induced by SP, surface hardening, and residual austenite transformation, contribute to improve erosion resistance of $18 \%$ white cast iron. However, series with a tempering and double tempering treatment after the quenching show a higher weight loss. On the other hand, and only comparing the tempered specimens, it is important to mention that in the case of double tempered specimen the estimated weight loss was lower, mainly due to the presence of very hard precipitated secondary carbides $\left(\mathrm{Fe}_{3} \mathrm{C}\right)$.

\section{Conclusions}

A total of $18 \%$ chromium white cast iron, usually used in wear resistant parts (mineral processing, cement production, and steel manufacturing industries), was submitted to different treatments, thermal and mechanical, with the aim of improving its erosion wear behavior.

Samples submitted to shot peening treatment show the best erosion behavior of all series, due to the induced top surface hardening and the complete transformation of the residual austenite in the upper layer of the material because of the plastic deformation induced by the treatment.

Nevertheless, tempering treatment $\left(500{ }^{\circ} \mathrm{C}-8 \mathrm{~h}\right)$, which was applied after quenching in air $\left(1000^{\circ} \mathrm{C}-6 \mathrm{~h}\right)$, produces the destabilization of austenite (slight amount remaining), resulting in an increase of martensite. After the second tempering treatment $\left(500{ }^{\circ} \mathrm{C}-8 \mathrm{~h}\right)$ the amount of residual austenite remains similar, while a partial redissolution of small $\mathrm{K}_{2}$ carbides takes place and superior bainite $\left(\mathrm{CFe}_{3}\right)(12 \%)$ is formed. In both cases, after tempering, the material became softer and the 
weight loss after erosion test was higher. Between these two series, double tempered specimens show better erosion wear behavior (lower weight loss) than simple tempered ones, mainly due to the presence of very hard precipitated secondary carbides $\left(\mathrm{Fe}_{3} \mathrm{C}\right)$.

The analysis of the results indicates that shot peening could be an interesting treatment to improve erosion wear behavior of $18 \%$ chromium white cast iron components, while decreasing energetic costs and manufacturing times associated to long tempering treatments.

Author Contributions: Data curation, A.Z.; Formal analysis, L.B.P. and A.Z.; Investigation, J.G.; Methodology, J.G. and L.B.P.; Supervision, I.F.-P.; Validation, I.F.-P.; Writing - original draft, J.G.; Writing - review \& editing, I.F.-P.

Funding: Resources of the department of materials science and metallurgical engineering of the University of Oviedo.

Conflicts of Interest: There are no conflicts of interest in this research.

\section{References}

1. Rundman, K.B.; Lacoviello, F. Cast Irons, 2nd ed.; Elsevier Inc.: Amsterdam, The Netherlands, 2016.

2. Singh, R. Applied Welding Engineering; Processes; Codes and Standards; Butterworth-Heinemann: Oxford, UK, 2015.

3. Matsubara, Y.; Sasaguri, N.; Shimizu, K.; Yu, S.K. Solidification and abrasion wear of white cast irons alloyed with $20 \%$ carbide forming elements. Wear 2001, 250, 502-510. [CrossRef]

4. Adler, T.A.; Dogan, Ö.N. Erosive wear and impact damage of high-chromium white cast irons. Wear 1999, 225-229, 174-180. [CrossRef]

5. Çetinkaya, C. An investigation of the wear behaviours of white cast irons under different compositions. Mater. Des. 2006, 27, 437-445. [CrossRef]

6. Jia, X.; Hao, Q.; Zuo, X.; Chen, N.; Rong, Y. High hardness and toughness of white cast iron: The proposal of a novel process. Mater. Sci. Eng. A 2014, 618, 96-103. [CrossRef]

7. Karantzalis, A.E.; Lekatou, A.; Mavros, H. Microstructural Modifications of As-Cast High-Chromium White Iron by Heat Treatment. J. Mater. Eng. Perform. 2009, 18, 174-181. [CrossRef]

8. Tabrett, C.P.; Sare, I.R. The effect of heat treatment on the abrasion resistance of alloy white irons. Wear 1997, 203-204, 206-219. [CrossRef]

9. Wiengmoon, A.; Chairuangsri, T.; Brown, A.; Brydson, R.; Edmonds, D.V.; Pearce, J.T.H. Microstructural and crystallographical study of carbides in 30wt.\%Cr cast irons. Acta Mater. 2005, 53, 4143-4154. [CrossRef]

10. Tang, X.H.; Chung, R.; Pang, C.J.; Li, D.Y.; Hinckley, B.; Dolman, K. Microstructure of high (45 wt.\%) chromium cast irons and their resistances to wear and corrosion. Wear 2011, 271, 1426-1431. [CrossRef]

11. Laird, G.; Gundlach, R.; Röhrig, K. Abrasion-Resistant Cast Iron Handbook; American Foundry Society: Schaumburg, IL, USA, 2000.

12. Gundlach, R. High-alloy white irons. In ASM Handbook Volume 15: Casting, formerly 9th ed.; Metals Handbook; ASM International: Geauga County, OH, USA, 1988; pp. 395-448.

13. Schön, C.; Sinatora, A. Simulation of solidification paths in high chromium white cast irons for wear applications. Calphad 1998, 22, 437-448. [CrossRef]

14. Pero, J.; Plaza, D.; Verdeja, J.; Asensio, J. Metallographic Characterization of Hypoeutectic Martensitic White Cast Irons: Fe-C-Cr System. Mater. Charact. 1999, 43, 33-39. [CrossRef]

15. Albertin, E.; Sinatora, A. Effect of carbide fraction and matrix microstructure on the wear of cast iron balls tested in a laboratory ball mill. Wear 2001, 250, 492-501. [CrossRef]

16. Liu, F.; Jiang, Y.; Xiao, H.; Tan, J. Study on fragmentation and dissolution behavior of carbide in a hot-rolled hypereutectic high chromium cast iron. J. Alloys Compd. 2015, 618, 380-385. [CrossRef]

17. Fernández-Pariente, I.; Belzunce-Varela, F.J. Influencia de diversos tratamientos térmicos en la microestructura de una fundicion blanca con alto contenido en cromo. Rev. Metal. 2006, 42, 279-286.

18. Dogan, O.N.; Hawk, J.A.; Laird, Y.G., II. Solidification structure and abrasion resistance of high chromium white irons. Metall. Mater. Trans. A 1997, 28, 1315-1328. [CrossRef]

19. Fairhust, W.; Rohrig, K. Abrasion resistant high chromium cast irons. Foundry Trade J. 1974, 136, 685-698.

20. Pero, J.A. Fundiciones Férreas; Ed. Dossat: Madrid, Spain, 1994. 
21. Heino, V.; Kallio, M.; Valtonen, K.; Kuokkala, V.-T. The role of microstructure in high stress abrasion of white cast irons. Wear 2017, 388-389, 119-125. [CrossRef]

22. Cui, W.; San-Martín, D.; Rivera, P.E.J. Stability of retained austenite in martensitic high carbon steels. Part I: Thermal stability. Mater. Sci. Eng. A 2018, 711, 683-695. [CrossRef]

23. Cui, W.; Gintalas, M.; Rivera, P.E.J. Stability of retained austenite in martensitic high carbon steels. Part II: Mechanical stability. Mater. Sci. Eng. A 2018, 711, 696-703. [CrossRef]

24. Gasan, H.; Ertuk, F. Effects of a destabilization heat treatment on the microstructure and abrasive wear behavior of high chromium white cast iron investigated using different characterization techniques. Metall. Mater. Trans. A 2013, 44, 4993-5005. [CrossRef]

25. Ribeiro, L.; Barbosa, A.; Viana, F.; Baptista, A.M.; Dias, C.; Ribeiro, C.A. Abrasion wear behaviour of alloyed and chilled cast irons. Wear 2011, 270, 535-540. [CrossRef]

26. Bagherifard, S.; Slawik, S.; Fernández, I.; Pauly, C.; Mücklich, F.; Guagliano, M. Nanoscale surface modification of AISI 316L stainless steel by severe shot peening. Mater. Des. 2016, 102, 68-77. [CrossRef]

27. Guagliano, M.; Vergani, L. An approach for prediction of fatigue strength of shot peened components. Eng. Fract. Mech. 2004, 71, 501-512. [CrossRef]

28. Colombo, C.; Guagliano, M.; Vergani, L. Fatigue Crack Growth Behaviour of nitrided and Shot Peened Specimens. SID 2005, 1, 253-265.

29. Almen, J.O.; Black, P.H. Residual Stresses and Fatigue in Metals; McGraw-Hill: New York, NY, USA, 1963.

30. Bagherifard, S.; Fernández-Pariente, I.; Ghelichi, R.; Guagliano, M. Effect of severe shot peening on microstructure and fatigue strength of cast iron. Int. J. Fatigue 2014, 65, 64-70. [CrossRef]

31. Liu, J.; Pang, M. Fatigue life prediction of shot-peened steel. Int. J. Fatigue 2012, 43, 134-141. [CrossRef]

32. Real, E.; Rodríguez, C.; Belzunce, F.J.; Sanjurjo, P.; Canteli, A.F.; Fernández, I. Fatigue behaviour of duplex stainless steel reinforcing bars subjected to shot peening. Fatigue Fract. Eng. Mater. Struct. 2009, 32, 567-572. [CrossRef]

33. Bagherifard, S.; Fernández, I.; Ghelichi, R.; Guagliano, M. Fatigue behavior of notched steel specimens with nanocrystallized surface obtained by severe shot peening. Mater. Des. 2013, 45, 497-503. [CrossRef]

34. Fernández, I.; Guagliano, M. About the role of residual stresses and surface work hardening on fatigue $\Delta \mathrm{K}_{\mathrm{th}}$ of a nitrided and shot peened low-alloy steel. Surf. Coat. Technol. 2008, 202, 3072-3080. [CrossRef]

35. Mhaede, M. Influence of surface treatments on surface layer properties; fatigue and corrosion fatigue performance of AA7075 T73. Mater. Des. 2012, 41, 61-66. [CrossRef]

36. Hashemi, B.; Yazdi, M.R.; Azar, V. The wear and corrosion resistance of shot peened-nitrided 316L austeniticstainless steel. Mater. Des. 2011, 32, 3287-3292. [CrossRef]

37. González, J.; Bagherifard, S.; Guagliano, M.; Fernández, I. Influence of different shot peening treatments on surface state and fatigue behaviour of Al 6063 alloy. Eng. Fract. Mech. 2017, 185, 72-81. [CrossRef]

38. Imurai, S.; Thanachayanont, C.; Pearce, J.T.H.; Chairuangsri, T. Microstructure and erosion-corrosion behaviour of as-cast high chromium white irons containing molybdenum in aqueous sulfuric-acid slurry. Arch. Metal. Mater. 2015, 60, 919-923. [CrossRef]

39. McCusker, L.B.; von Dreele, R.B.; Cox, D.E.; Louërd, D.; Scardie, P. Rietveld refinement guidelines. J. Appl. Cryst. 1999, 32, 36-50. [CrossRef]

40. ASTM. E975-03 Standard Practice for X-Ray Determination of Retained Austenite in Steel with Near Random Crystallographic Orientation. ASTM Int. 2008, E975-13, 1-7.

(C) 2019 by the authors. Licensee MDPI, Basel, Switzerland. This article is an open access article distributed under the terms and conditions of the Creative Commons Attribution (CC BY) license (http://creativecommons.org/licenses/by/4.0/). 